\title{
Predictors and symptomatic burden of uterine fibroids among women in South-Eastern India: a cross-sectional survey analysis
}

\author{
Dharitri Swain*, Chanchal Yadav, Jyoti Kumari, Monika Rani, \\ Priyanka Daunrai Rongmei, Sehaj Kaur Khurana
}

College of Nursing, All India Institute of Medical Sciences (AIIMS), Bhubaneswar, Odisha, India

Received: 24 November 2018

Accepted: 29 December 2018

\author{
*Correspondence: \\ Dr. Dharitri Swain, \\ E-mail: dhari79@yahoo.co.in
}

Copyright: (C) the author(s), publisher and licensee Medip Academy. This is an open-access article distributed under the terms of the Creative Commons Attribution Non-Commercial License, which permits unrestricted non-commercial use, distribution, and reproduction in any medium, provided the original work is properly cited.

\begin{abstract}
Background: Uterine fibroid is the most common pelvic tumor in women of reproductive age and are asymptomatic in at least $50 \%$ of affected women. Various risk factors are associated with development of uterine fibroids during this reproductive age. The present study established various associated risk factors increases the prevalence of uterine fibroid among reproductive age group and clinical symptoms burden of diagnosed case.

Methods: A cross sectional study design was used to collect samples for a period of six months in an OPD basis. Purposive sampling technique was used to select the 362 sample of reproductive age group (15-45 years) women in a tertiary care hospital, Southeastern India. Women diagnosed with uterine fibroid by ultrasonography were included as cases. Symptomatic features and associated risk factors of UF were collected through structure interview schedule.

Results: Point prevalence of uterine fibroid among women in reproductive age group during the period of six months was $20 \%$. Majority of them were in the age group of 30-39 years. Demographic factor such as overweight and obesity and consume dairy products daily has increased the prevalence of UF, whereas use of oral contraceptive pills and normal BMI had inverse relationship with UF risk. Most of the cases reported of having menstrual disturbances like heavy bleeding, passes blood clots during menstruation, prolonged period, urinary symptoms and pressure symptoms were considered independent predicting factors for the occurrence of uterine fibroid.

Conclusions: Uterine fibroid is more prevalent among women of reproductive age causing various bleeding and renal symptoms that can have negative impact on quality of women's life.
\end{abstract}

Keywords: Determinants, Menstrual irregularities, Reproductive age group, Uterine fibroid

\section{INTRODUCTION}

Uterine leiomyoma is a highly prevalent, benign smooth muscle tumor of the uterus. They are the most common pelvic tumor in women of reproductive age and are asymptomatic in at least $50 \%$ of affected women. ${ }^{1,2}$ The global prevalence rate compromises of $21.4 \%$ among 30 60 years age group and highest prevalence range of fibroids estimates is 3-20\%, with African American and older women., ${ }^{3,4}$ The frequency of uterine fibroid is presented differently among women of different age group. But cause of uterine fibroid is poorly reported yet represent an important gynecological pathology condition and mostly associated with abnormal uterine bleeding, pelvic pain and may have reproductive effects on infertility and adverse pregnancy outcomes. ${ }^{4}$

There is considerable evidence that estrogens and progestrogens proliferate tumor growth as the fibroids rarely appear before menarche and regress after menopause., ${ }^{5,6}$ Hormonal disturbances and genetic alterations are postulated to contribute to the 
development of uterine leiomyoma, although their precise functions are not completely understood.,

Fibroids develop in women between the ages of 30-50 years. Approximately $25 \%$ of Indian women in their reproductive years have noticeable fibroids. According to a 2010 World Health Organization report, fibroids affects between $20-25 \%$ of middle and later reproductive women, and close to 235 million women which represent $6.6 \%$ of global women population are estimated to have been affected worldwide..$^{3,9}$

Literature shows that risk factors for development of uterine fibroids includes nulli-parity, early menarche, increased frequency of menses, history of dysmenorrhoea, family history of uterine fibroids, obesity, and age. ${ }^{10,11}$

There is less evidence of uterine fibroid prevalence among Indian women of reproductive age group and therefore, the aim of this study was to assess the prevalence of fibroids in present population of reproductive age group women and to discover possible risk factors for its occurrence and associated symptom burden.

\section{METHODS}

A cross sectional study was conducted among women of reproductive age group attending tertiary care hospital, Bhubaneswar, Odisha. The sample size was 362; it was calculated by open EPI software. Non-probability purposive sampling technique was used to select the sample.

The structured questionnaire was developed based on previous studies and literature review and validated by five experts from senior gynecologist and senior nursing faculties.

Content validity was measured by Content validity index (CVI) was 0.91 , KMO coefficient of structured validity was 0.712 and reliability coefficient of the tool was measured by cronbach alpha, found to be reliable $(\mathrm{r}=0.7)$.

The tool consists section A: demographic variables such as age, marital status, weight, $\mathrm{BMI}, \mathrm{Hb} \%$, parity, family history, dietary pattern, and section B: structured interview schedule containing 18 questions item based on clinical symptoms, physical activities, sexual functioning and psychological disturbance.

The data was collected from February to July 2018. During the data collection process, the women were interviewed in outpatient basis through structured interview schedule.

Ethical consideration was obtained by taking written permission from the authority of the hospital. Permission was obtained from Institutional Ethical Review Board,
AIIMS, Bhubaneswar. Self-introduction and the purpose of the study to the participants were explained. Informed consent was obtained from the study samples and interviewed patients to get the information. Confidentiality and anonymity were assured.

\section{Inclusion criteria}

- Women of reproductive age group (15-45) years, who were undergone ultra sound during data collection period and diagnosed case of uterine fibroid were analyzed for finding the risk factors.

\section{Statistical analysis}

Data was analyzed using statistical package for Social Science programme version (SPSS) 20. Descriptive statistics like frequency and percentage were used to describe the demographic characteristics and determinants of uterine fibroid. Inferential statistics such as chi square test was used to find out the significant association between study variables.

\section{RESULTS}

\section{Descriptive statistic}

The result of the study was that overall point prevalence of diagnosed ultrasonography uterine fibroids was $20 \%$ and it ranged from $4.5 \%$ (20-29 years) to $9.4 \%$ (30-39 years), reaching $6.6 \%$ (40-45 years) among the age group of 15-45 years. The mean age of the women with uterine fibroid was 35 years.

Majority (20.2\%) were married, multigravida (14.1\%), primigravida $(5.5 \%)$ and only $1.1 \%$ were nulligravida. There were less cases $(6 \%)$ reported family history of uterine fibroid and $9.4 \%$ had reported the history of taking oral contraceptive pills.

With respect to nutritional status, $6.1 \%$ were underweight, $11.3 \%$ were overweight and fewer proportions $(3.3 \%)$ of women were normal weight. In regard to dietary pattern $15.7 \%$ were non-vegetarian, $17.1 \%$ had reported of taking regular dairy products.

Most of the participants were below the normal range of hemoglobin which accounts of $18.5 \%$ of women were suffering from anemia among the participants diagnosed with uterine fibroid.

Demographic factor such as overweight and obesity $(\mathrm{p}=0.000)$ and consume dairy products daily $(\mathrm{p}=0.000)$ has increased the prevalence of UF, whereas use of oral contraceptive pills and normal BMI had inverse relationship with UF risk ( $\mathrm{p}=0.005)$.

Other demographic variable such as age, marital status, parity, tobacco habits and hereditary factors were found not associated with uterine fibroid prevalence (Table 1). 
Table 1: Association between the uterine fibroid and selected demographic variable among reproductive age women $(n=362)$.

\begin{tabular}{|c|c|c|c|c|c|}
\hline \multirow[t]{2}{*}{ Characteristics } & \multicolumn{2}{|c|}{$\begin{array}{l}\text { Non- } \\
\text { diagnosed } \\
\text { case }\end{array}$} & \multicolumn{2}{|c|}{$\begin{array}{l}\text { Diagnosed } \\
\text { case }\end{array}$} & \multirow[t]{2}{*}{$\begin{array}{l}P \\
\text { value }\end{array}$} \\
\hline & $\mathbf{N}$ & $\%$ & $\mathbf{N}$ & $\%$ & \\
\hline \multicolumn{6}{|l|}{ Age } \\
\hline 20 to 29 & 70 & 19.3 & 17 & 4.7 & \multirow{3}{*}{0.709} \\
\hline 30 to 39 & 115 & 31.8 & 34 & 9.4 & \\
\hline 40 to 45 & 102 & 28.2 & 24 & 6.6 & \\
\hline \multicolumn{6}{|l|}{ Marital status } \\
\hline Married & 0 & 0 & 02 & 0.6 & \multirow{2}{*}{0.042} \\
\hline Unmarried & 287 & 79.3 & 73 & 20.2 & \\
\hline \multicolumn{6}{|l|}{ BMI } \\
\hline Underweight & 71 & 19.6 & 22 & 6.1 & \multirow{3}{*}{0.286} \\
\hline Normal & 146 & 40.3 & 12 & 3.3 & \\
\hline $\begin{array}{l}\text { Overweight and } \\
\text { obesity }\end{array}$ & 70 & 19.3 & 41 & 11.32 & \\
\hline \multicolumn{6}{|l|}{ Parity } \\
\hline Nulligravida & 11 & 3.0 & 04 & 1.1 & \multirow{3}{*}{0.829} \\
\hline Primigravida & 81 & 22.4 & 20 & 5.5 & \\
\hline Multigravida & 195 & 53.9 & 51 & 14.1 & \\
\hline \multicolumn{6}{|c|}{ Family history of UF } \\
\hline No & 275 & 76.0 & 67 & 18.5 & \multirow{2}{*}{0.029} \\
\hline Yes & 12 & 3.3 & 8 & 2.2 & \\
\hline \multicolumn{6}{|c|}{ Oral contraceptive history } \\
\hline No & 181 & 50.0 & 41 & 11.3 & \multirow{2}{*}{0.005} \\
\hline Yes & 106 & 29.3 & 34 & 9.4 & \\
\hline \multicolumn{6}{|l|}{ Dietary pattern } \\
\hline $\begin{array}{l}\text { No regular dairy } \\
\text { products }\end{array}$ & 116 & 22.1 & 13 & 3.6 & \multirow{2}{*}{0.000} \\
\hline $\begin{array}{l}\text { Regular dairy } \\
\text { products }\end{array}$ & 171 & 57.2 & 62 & 17.1 & \\
\hline \multicolumn{6}{|l|}{ Tobacco chewing } \\
\hline No & 240 & 66.3 & 58 & 16.0 & \multirow{2}{*}{0.204} \\
\hline Yes & 47 & 13.0 & 17 & 4.7 & \\
\hline \multicolumn{6}{|l|}{ Hb\% status } \\
\hline Anaemic & 264 & 72.9 & 67 & 18.5 & \multirow{2}{*}{0.465} \\
\hline Non anaemic & 23 & 6.4 & 8 & 2.2 & \\
\hline
\end{tabular}

Clinical symptoms burden in diagnosed uterine fibroid among reproductive age women

Risk factors of uterine fibroid are presented in the figures. $20 \%$ women experienced weight loss. More than half of the respondents (54\%) had menstrual problems: among them $46 \%$ women experienced heavy bleeding, $44 \%$ had prolonged periods during menstruation, $32 \%$ complained bleeding between periods, $28 \%$ experienced frequent period and $34 \%$ felt pain during menstruation (Figure 1).

A quarter of participants complained of bowel and bladder symptoms: among them $34 \%$ experience frequent urination during the daytime whereas $23 \%$ experience frequent night-time urination, also $60 \%$ of them had complain of pressure symptoms (Figure 2).

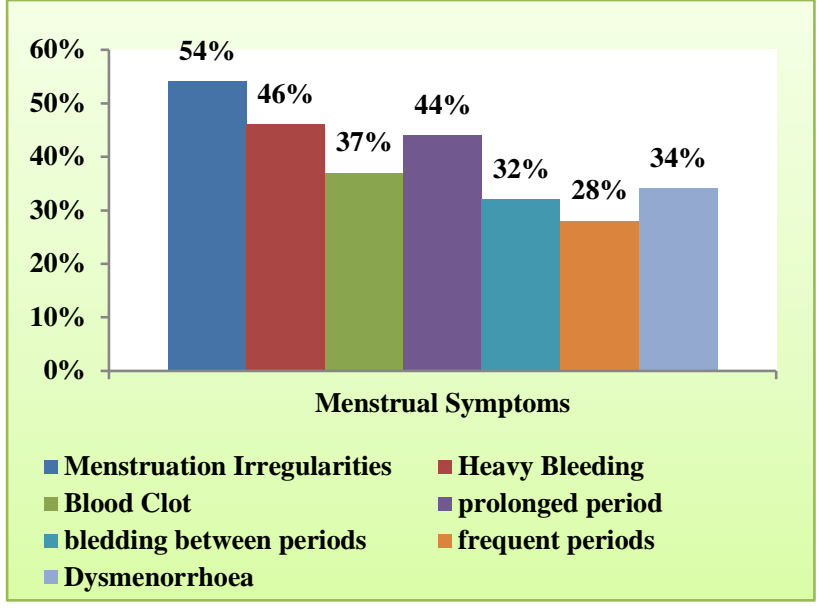

Figure 1: Menstrual symptoms.

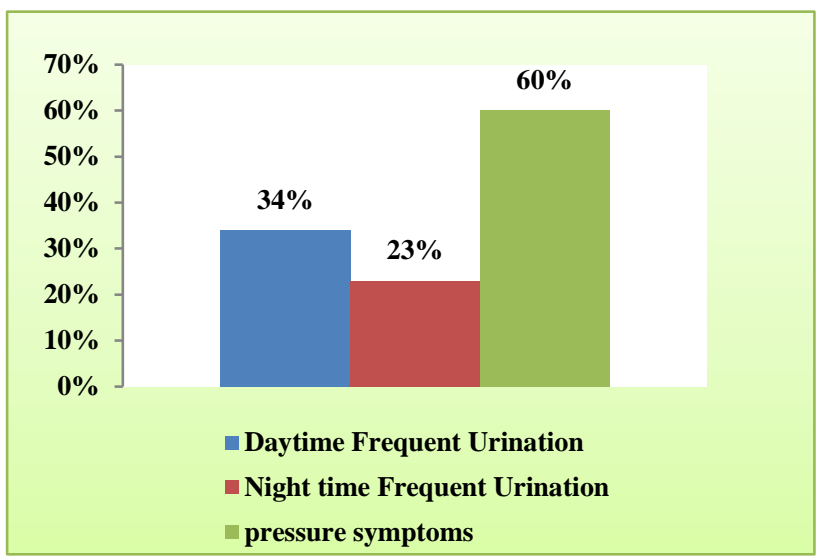

Figure 2: Bladder and bowel symptoms.

Some participant also had burden of altered physical, psychological and sexual functioning: $56 \%$ women experienced disturbance in the daily physical activities, $47 \%$ women felt stressful and embarrassment due to disease condition and only $8 \%$ women complained of pain during sexual intercourse. Also, very less participants (9\%) had gynecological infections (Figure 3).

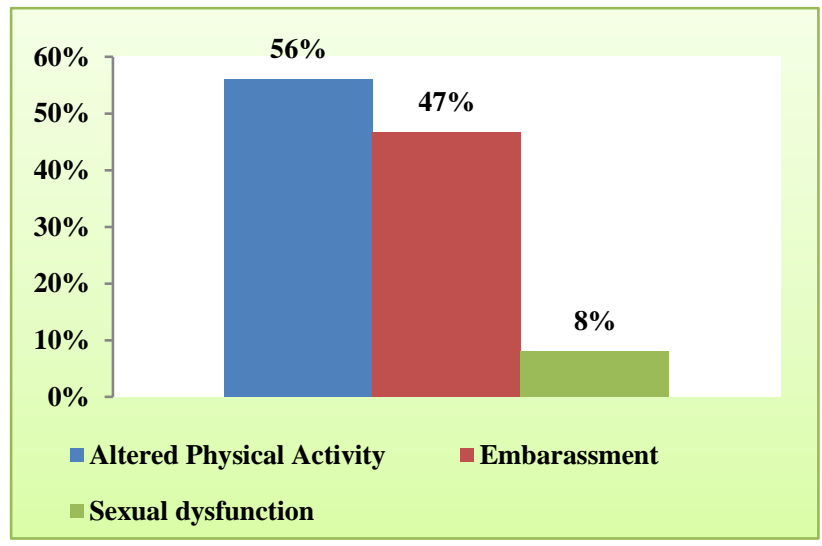

Figure 3: Physical, psychological and sexual functioning. 
Association between clinical symptoms and prevalence of the uterine fibroid among reproductive age women

Table 2 depicts the major findings related to risk participants having heavy bleeding $(\mathrm{p}=0.000)$, passes blood clots during menstruation $(\mathrm{p}=0.000)$, prolonged period ( $\mathrm{p}=0.001)$, participants feeling tightness of pelvic area $(p=0.002)$ were found significantly associate with uterine fibroid.

Table 2: Risk factors of uterine fibroid among reproductive age women $(n=362)$.

\begin{tabular}{|c|c|c|c|c|c|}
\hline \multirow[t]{2}{*}{ Characteristics } & \multicolumn{2}{|c|}{$\begin{array}{l}\text { Non- } \\
\text { diagnosed } \\
\text { case }\end{array}$} & \multicolumn{2}{|c|}{$\begin{array}{l}\text { Diagnosed } \\
\text { case }\end{array}$} & \multirow[t]{2}{*}{$\begin{array}{l}\mathbf{P} \\
\text { value }\end{array}$} \\
\hline & $\mathbf{N}$ & $\%$ & $\mathbf{N}$ & $\%$ & \\
\hline \multicolumn{6}{|c|}{ Gynaecological infection } \\
\hline No & 264 & 72.9 & 64 & 17.7 & \multirow{2}{*}{0.079} \\
\hline Yes & 23 & 6.4 & 11 & 3.0 & \\
\hline \multicolumn{6}{|c|}{ Gynaecological surgery } \\
\hline No & 265 & 73.2 & 65 & 18.0 & \multirow{2}{*}{0.124} \\
\hline Yes & 22 & 6.1 & 10 & 2.8 & \\
\hline \multicolumn{6}{|l|}{ Weight loss } \\
\hline No & 251 & 69.3 & 38 & 10.5 & \multirow{2}{*}{$0.000 *$} \\
\hline Yes & 36 & 9.9 & 37 & 10.2 & \\
\hline \multicolumn{6}{|l|}{ Heavy bleeding } \\
\hline No & 195 & 53.9 & 29 & 8.0 & \multirow{2}{*}{$0.000 *$} \\
\hline Yes & 92 & 25.4 & 46 & 12.7 & \\
\hline \multicolumn{6}{|l|}{ Pass blood clots } \\
\hline No & 197 & 54.4 & 31 & 8.6 & \multirow{2}{*}{$0.000 *$} \\
\hline Yes & 90 & 24.9 & 44 & 12.2 & \\
\hline \multicolumn{6}{|c|}{ Fluctuation in duration-prolonged period } \\
\hline No & 173 & 47.8 & 29 & 8.0 & \multirow{2}{*}{$0.001 *$} \\
\hline Yes & 114 & 31.5 & 46 & 12.7 & \\
\hline \multicolumn{6}{|c|}{ Fluctuation in the length-frequent period } \\
\hline No & 161 & 44.5 & 38 & 10.5 & \multirow{2}{*}{0.400} \\
\hline Yes & 126 & 34.8 & 37 & 10.2 & \\
\hline \multicolumn{6}{|c|}{ Bleeding between period } \\
\hline No & 161 & 44.5 & 51 & 10.5 & \multirow{2}{*}{0.410} \\
\hline Yes & 126 & 34.8 & 24 & 32 & \\
\hline \multicolumn{6}{|c|}{ Tightness of pelvic area-pressure symptoms } \\
\hline No & 173 & 47.8 & 30 & 8.3 & \multirow{2}{*}{$0.002 *$} \\
\hline Yes & 114 & 31.5 & 45 & 12.4 & \\
\hline \multicolumn{6}{|c|}{ Frequent urination daytime } \\
\hline No & 227 & 62.7 & 49 & 13.5 & \multirow{2}{*}{0.013} \\
\hline Yes & 60 & 16.6 & 26 & 7.2 & \\
\hline Frequent night- & me ur & nation & & & \\
\hline No & 251 & 69.3 & 58 & 16.0 & \\
\hline Yes & 36 & 9.9 & 17 & 4.7 & 0.027 \\
\hline Altered daily ph & sical : & ctivitie & & & \\
\hline No & 115 & 31.8 & 33 & 9.1 & 0538 \\
\hline Yes & 172 & 47.5 & 42 & 11.6 & 0.538 \\
\hline Stressful and en & arras & ment & e to & his dise & \\
\hline No & 196 & 54.1 & 40 & 11.0 & 001 \\
\hline Yes & 91 & 25.1 & 35 & 9.7 & 0.015 \\
\hline Altered sexual a & ivity & & & & \\
\hline No & 264 & 72.9 & 69 & 19.1 & \\
\hline Yes & 23 & 6.4 & 6 & 1.7 & 0.997 \\
\hline
\end{tabular}

However, no association was found with uterine fibroid with family history of uterine fibroid $(\mathrm{p}=0.029)$, gynecological infection $(\mathrm{p}=0.079)$, gynecological surgery $(\mathrm{p}=0.124)$, habit of chewing tobacco $(\mathrm{p}=0.204)$, fluctuation in the length of menstruation $(p=0.400)$, frequent urination daytime $(\mathrm{p}=0.013)$, Frequent nighttime urination $(\mathrm{p}=0.027)$.

Also altered in physical and sexual function had no significant association with UF prevalence (Table 2).

\section{Logistic regression model determining predictors for uterine fibroid among reproductive age women}

To determine the predictors of uterine fibroid, forward stepwise method of logistic regression analysis was used for statistically significant factors listed in Table 3.

Logistic regression analysis showed that consume dairy products daily, menstrual symptoms like heavy bleeding, pass blood clots, prolonged period, urinary symptoms such as frequent urination in day and night time, pressure symptoms such as feeling tightness in pelvic area and stressed and embarrassment due to disease were considered independent risk factors for the occurrence of uterine fibroid but use of oral contraceptives pills and lower BMI has lowered the chance of occurring UF (Table 3 ).

Table 3: Multivariate logistic regression analysis on the occurrence of uterine fibroid among reproductive age women $(n=362)$.

\begin{tabular}{|c|c|c|c|}
\hline Characteristics & $\begin{array}{l}\text { OR } \\
(95 \% \mathrm{CI})\end{array}$ & $\begin{array}{l}\text { AOR } \\
(95 \% \mathrm{CI})\end{array}$ & $\begin{array}{l}P \\
\text { value }\end{array}$ \\
\hline $\begin{array}{l}\text { Oral } \\
\text { contraceptives } \\
\text { pills }\end{array}$ & $\begin{array}{l}0.72 \\
(0.20-1.23)\end{array}$ & $\begin{array}{l}2.05 \\
(1.23-3.44)\end{array}$ & $0.006^{*}$ \\
\hline Low BMI & $\begin{array}{l}1.91 \\
(1.34-2.48)\end{array}$ & $\begin{array}{l}6.78 \\
(3.83-12.02)\end{array}$ & $0.000^{*}$ \\
\hline $\begin{array}{l}\text { Consume dairy } \\
\text { products daily }\end{array}$ & $\begin{array}{l}1.17 \\
(0.53-1.81)\end{array}$ & $\begin{array}{l}3.23 \\
(1.70-6.15)\end{array}$ & $0.000^{*}$ \\
\hline $\begin{array}{l}\text { Heavy } \\
\text { bleeding }\end{array}$ & $\begin{array}{l}1.21 \\
(0.68-1.73)\end{array}$ & $\begin{array}{l}3.36 \\
(1.98-5.69)\end{array}$ & $0.000^{*}$ \\
\hline $\begin{array}{l}\text { Pass } \\
\text { blood clots }\end{array}$ & $\begin{array}{l}1.13 \\
(0.61-1.65)\end{array}$ & $\begin{array}{l}3.10 \\
(1.84-5.24)\end{array}$ & $0.000^{*}$ \\
\hline $\begin{array}{l}\text { Prolonged } \\
\text { period }\end{array}$ & $\begin{array}{l}0.87 \\
(0.35-1.39)\end{array}$ & $\begin{array}{l}2.40 \\
(1.42-4.05)\end{array}$ & $0.001 *$ \\
\hline $\begin{array}{l}\text { Pressure } \\
\text { symptoms }\end{array}$ & $\begin{array}{l}0.82 \\
(0.30-1.34)\end{array}$ & $\begin{array}{l}2.27 \\
(1.35-3.82)\end{array}$ & $0.002 *$ \\
\hline $\begin{array}{l}\text { Frequent } \\
\text { urination } \\
\text { daytime }\end{array}$ & $\begin{array}{l}0.69 \\
(0.14-1.25)\end{array}$ & $\begin{array}{l}2 \\
(1.15-3.49)\end{array}$ & $0.014 *$ \\
\hline $\begin{array}{l}\text { Frequent } \\
\text { night-time } \\
\text { urination }\end{array}$ & $\begin{array}{l}0.71 \\
(0.07-1.35)\end{array}$ & $\begin{array}{l}2.04 \\
(1.07-3.88)\end{array}$ & $0.030 *$ \\
\hline $\begin{array}{l}\text { Stressed and } \\
\text { embarrassment } \\
\text { due to disease }\end{array}$ & $\begin{array}{l}0.63 \\
(0.11-1.15)\end{array}$ & $\begin{array}{l}1.88 \\
(1.12-3.16)\end{array}$ & $0.016^{*}$ \\
\hline
\end{tabular}




\section{DISCUSSION}

The findings of the study were discussed with reference to the objectives and hypothesis and with the findings of the previous studies. Uterine fibroid occurring as the most common pelvic tumor in women with a prevalence rate of $21.4 \%$ globally. ${ }^{3}$ An international internet-based survey of 21,746 women which was done by online method approach and self-reported prevalence of uterine fibroids ranged from $4.5 \%$ (UK) to $9.8 \%$ (Italy), reaching $9.4 \%$ (UK) to $17.8 \%$ (Italy) in the age group of $40-49$ years. ${ }^{10}$ Whereas only $5 \%$ case of uterine fibroid reported in a survey conducted in US among 59411 women of aged 18-54 years and $6.83 \%$ among 2575 female patients in south western Nigerian population and $15 \%$ was reported among ultrasound-diagnosed fibroids in which more found in black women compared to white women and $21.1 \%$ in north east Slovenia. ${ }^{11-14}$ The global prevalence rate is more close to Indian scenario $24 \%$ among 46-50 years age group in rural South Indian women which supports present study prevalence rate of $20 \%$ among women of reproductive age. ${ }^{15}$

This prevalence rate of UF was more among young age group $<30$ years, the peak of detected fibroids was at the age of 39, after which the prevalence of fibroids was decreasing until the age of 45 years. Advanced age above 45 was not studied in present study. Previous study also supports age of the patients is significantly associated with the prevalence of fibroids, lower rate found among younger women and increases to the peak at the age of 49 and decreased significantly after age of $50 .{ }^{14}$ This can be justifiable that growth of fibroid is depending upon hormone level; therefore, the prevalence rate varied in different age groups. ${ }^{16}$ Hence the fibroids may significantly reduce their size during menopause period due to exposed to lower levels of female sex hormones. ${ }^{17}$

The epidemiological factors for development of uterine fibroids includes nulli-parity, obesity, age, family history of uterine fibroids, prenatal hormone exposure, polycystic ovary syndrome, diabetes and hypertension. ${ }^{10,11,18-23}$ Present study findings did not show any statistical significant with these epidemiological factors but more number of cases reported among advanced age. It was reported that obese and high body mass index increases risk of uterine fibroids compared with low BMI. ${ }^{18,19,24,25}$ These results are consistent with present results showed that BMI in women was in average $0.9 \mathrm{~kg} / \mathrm{m}^{2}$ higher with fibroids compared to women without fibroids. Present results showed that the prevalence of fibroids was higher $(11.32 \%)$ in women with BMI between 26 and $29 \mathrm{~kg} / \mathrm{m}^{2}$ than in women with a BMI between 17.5 to $23.9 \mathrm{~kg} / \mathrm{m}^{2}$ $(3.3 \%)$.

Some factors reduced UF risk and have like use of oral contraceptive or the injectable contraceptive depot medroxy progesterone acetate, smoking in women, with low body mass index and parity. ${ }^{26,27}$ Also present study established an inverse relationship between history of taking oral contraceptive pills, consume dairy products daily and low body mass index with prevalence of uterine fibroids. Genetic and hereditary as the major cause and the genetic influence especially for early onset of uterine fibroid. ${ }^{7,8,27}$ But present study found a very negligible percentage $(6 \%)$ had family history of uterine fibroid and genetic exploration was not under the scope of present study.

Uterine fibroid cases are mostly asymptomatic and the symptoms of fibroid uterus found $81 \%$ of symptomatic patient comes with complains menstrual irregularities. ${ }^{28}$ Present study found maximum cases complained irregularities during menstrual period (54\%) and had more bleeding symptoms such as heavy bleeding $(38 \%)$ prolonged bleedings $(44 \%)$, bleeding between periods $(32 \%)$, frequent periods $(28 \%)$, dysmenorrhoea $(34 \%)$. present study result is matching to the result published in previous studies reported more menstrual symptoms like menorrhagia, dysmenorrhea, metrorrhagia, polymenorrhea, and leucorrhoea. ${ }^{15,28,29}$

Present study reveals participants also reported about bowel and bladder symptoms, among them $24 \%$ experience frequent urination during the daytime whereas $15 \%$ experience frequent night-time urination, $44 \%$ experienced tightness of pelvic area and also $8 \%$ women complained of pain during sexual intercourse in case of fibroids present near the vagina or cervix. Study finding was supported with previous studies which shows that women mostly experienced lower back pain, bladder or bowel symptoms and complained of pain during sexual intercourse. ${ }^{30}$

Present study also explored patient experiencing physical and psychological disturbances due to disease process found $59 \%$ women experienced disturbance in the daily physical activities, self-reported stress among $27 \%$ women and $35 \%$ women felt embarrassment due to disease condition. A supportive study agreed the symptom burden of uterine fibroid influences the quality of women's life. ${ }^{30}$

Menstrual irregularities like bleeding symptoms, blood clots during menstruation, fluctuation in the duration of menstruation, renal symptoms and pressure symptoms are predictors of uterine fibroid risk depicted in present study findings. These results are consistent with other previous studies.

The literature reviews related lifestyle risk factors of UF including diet, physical activity and stress and occupational intensity on uterine fibroids, has no significant association with risk of uterine fibroid in women. ${ }^{31}$ Present study found the similar reports that there is no effect of gynecological infection, gynecological surgery, habit of chewing tobacco, altered physical and sexual functions on prevalence of uterine fibroid with history bur dietary habits of taking more dairy products had impact on uterine fibroid risk. 


\section{CONCLUSION}

A study of 75 cases of fibroids was made over a period of six months among 362 samples which supports uterine fibroids are the commonest tumour of the reproductive age. Uterine fibroids are not monopoly of null parity but also to multigravida. The incidence of anaemia, heavy bleeding with clots and metrorrhagia in fibroids is quite high to a contrary which effect to psychological condition by embarrassment due to disease condition which a result interferes daily activity. At times fibroids are asymptomatic and do not require treatment, contrast to this sometimes sever symptoms like menorrhagia, dysmenorrhoea and pressure symptoms occur which makes treatment necessary which can have a negative impact on different aspects of women's life.

\section{ACKNOWLEDGMENTS}

Authors would like to thank study participants, experts for validating the tool and student investigators for data management and drafting the manuscripts.

Funding: No funding sources

Conflict of interest: None declared

Ethical approval: The study was approved by the Institutional Ethical Review Board, AIIMS, Bhubaneswar

\section{REFERENCES}

1. Graves WP. Uterine myomata (fibroids). In: Curtis $\mathrm{AH}$, ed. Obstetrics and Gynecology, $2^{\text {nd }}$ vol. WB Saunders: Philadelphia. 1933:745-783.

2. Baird DD, Dunson DB, Hill MC, Cousins D, Schectman JM. High cumulative incidence of uterine leiomyoma in black and white women: ultrasound evidence. Am J Obstet Gynecol. 2003;188(1):100-7.

3. Marino JL, Eskenazi B, Warner M, Samuels S, Vercellini S, Gavoni N, et al. Uterine leiomyoma and menstrual cycle characteristics in a population based cohort study. Hum Reprod. 2004;19:2350-5.

4. Ekine AA, Lawani LO, Iyoke CA, Jeremiah I, Ibrahim IA. Review of the clinical presentation of uterine fibroid and the effect of therapeutic intervention on fertility. Am J Clin Med Res. 2015;3:9-13.

5. Wise LA, Palmer JR, Harlow BL, Spiegelman D, Stewart EA, Adams-Campbell LL, et al. Reproductive factors, hormonal contraception and risk of uterine leiomyomata in African- American women: a prospective study. Am J Epidemiol. 2004;159(2):113-23.

6. Rein MS, Barbieri RL, Friedman AJ. Progesterone: a critical role in the pathogenesis of uterine myomas. Am J Obstet Gynecol. 1995;172(1 Pt 1):14-8.

7. Andersen J. Growth factors and cytokines in uterine leiomyomas. Semin Reprod Endocrinol. 1996;14(3):269-82.

8. Moravek MB, Bulun SE. Endocrinology of uterine fibroids: steroid hormones, stem cells, and genetic contribution. Current Opinion Obstet Gynecol. 2015;27(4):276.

9. Naik $S$, Nathan LT. Indian prevalence rate, fibroid uterus. National Institute of Health Science. 2006:275-8.

10. Zimmermann A, Bernuit D, Gerlinger C, Schaefers M, Geppert K. Prevalence, symptoms and management of uterine fibroids: an international internet-based survey of 21,746 women. BMC Women's Health. 2012;12(1):6.

11. Fuldeore MJ, Soliman AM. Patient reported prevalence and symptomatic burden of uterine fibroids among women in the united states: finding from a cross sectional survey. Int J Womens Health. 2012; 9:403-11.

12. Ukwenya V, Maduemezia N, Afolayan O, Alese O, Thomas W. Prevalence of uterine fibroid in a SouthWestern Nigerian population: A sonographic study. J Exp Clin Anatomy. 2015;14(1):24-9.

13. Borgfeldt C, Andolf E. Transvaginal ultrasonographic findings in the uterus and the endometrium: low prevalence of leiomyoma in a random sample of women age 25-40 years. Acta Obstet Gynecol Scand. 2000;79:202-7.

14. Bizjak T, Bečić A, But I. Prevalence and Risk Factors of Uterine Fibroids in North-East Slovenia. Gynecol Obstet. 2016;6(01):350.

15. Munusamy MM, Sheelaa WG, Lakshmi VP. Clinical presentation and prevalence of uterine fibroids: a 3year study in 3-decade rural South Indian women. Int J Reprod Contracept Obstet Gynecol. 2017;6(12):5596-601.

16. Terry KL, De Vivo I, Hankinson SE, Missmer SA. Reproductive characteristics and risk of uterine leiomyomata. Fertil Steril. 2010;94:2703-7.

17. Blake RE. Leiomyomata uteri: hormonal and molecular determinants of growth. J Natl Med Assoc. 2007;99:1170-84.

18. Flake GP, Andersen J, Dixon D. Etiology and pathogenesis of uterine leiomyomas: a review. Environ Health Perspect. 2003;111:1037-54.

19. Lumbiganon $P$, Rugpao S, Phandhu-fung S, Laopaiboon M, Vudhikamraksa N, et al. Protective effect of depot-medroxyprogesterone acetate on surgically treated uterine leiomyomas: a multicentre case-control study. BJOG. 1996;103:909-14.

20. Flake GP, Andersen J, Dixon D. Etiology and pathophysiology of uterine leiomyomas; a review. Environ Health Perspect. 2003;111:1037-54.

21. Okolo S. Incidence, aetiology and epidemiology of uterine fibroids. Best Pract Res Clin Obstet Gynaecol. 2008;22:571-88.

22. Commandeur AE, Styer AK, Teixeira JM. Epidemiological and genetic clues for molecular mechanisms involved in uterine leiomyoma development and growth. Hum Reprod Update. 2015;21:593-615.

23. Stewart EA, Cookson CL, Gandolfo RA, SchulzeRath R. Epidemiology of uterine fibroids: a systematic review. BJOG. 2017;124(10):1501-12. 
24. Abbas HY, Awad IA, Alharbi E, Alaameri H, Althubaiti S, Ashkar L. Prevalence and incidence of uterine fibroid at King Abdulaziz University Hospital Saudi Arabia. Clinical Med Diagnos. 2016;6(3):45-8.

25. Payson M, Leppert P, Segars J. Epidemiology of Myomas. Obstet Gynecol Clin North Am. 2006;33:1-11.

26. Ross RK, Pike MC, Vessey MP, Bull D, Yeates D, et al. Risk factors for uterine fibroids: reduced risk associated with oral contraceptives. $\mathrm{Br}$ Med J. 1986;293:359-62.

27. Hodge JC, Morton CC. Genetic heterogeneity among uterine leiomyomata: insights into malignant progression. Hum Mol Genet. 2007;16(R1):R7-R13.

28. Khyade, RL. A study of menstrual disturbance in cases of fibroid uterus. Int $\mathrm{J}$ Reprod Contracept Obstet Gynecol.2017;6(6):2494-7.

29. Bachmann GA, Bahouth LA, Amalraj P, Mhamunkar $\mathrm{V}$, Hoes $\mathrm{K}$, Ananth CV. Uterine fibroids: Correlations of anemia and pain to fibroid location and uterine weight. J Reprod Med. 2011;56(1112):463-6.

30. Brito LG, Panobianco MS, Sabino-de-Freitas MM, de Freitas Barbosa H, de Azevedo GD, Brito LM, et al. Uterine leiomyoma: understanding the impact of symptoms on womens' lives. Reprod Health. 2014;11(1):10.

31. He Y, Zeng Q, Dong SY, Qin LQ, Li GW, Wang PY. Associations between uterine fibroids and lifestyles including diet, physical activity and stress: a case-control study in China. Asia Pacific J Clin Nutr. 2013;22(1):109-17.

Cite this article as: Swain D, Yadav C, Kumari J, Rani M, Rongmei PD, Khurana SK. Predictors and symptomatic burden of uterine fibroids among women in South-Eastern India: a cross-sectional survey analysis. Int J Reprod Contracept Obstet Gynecol 2019;8:524-30. 